\title{
COX6C Gene
}

National Cancer Institute

\section{Source}

National Cancer Institute. COX6C Gene. NCI Thesaurus. Code C24308.

This gene is involved in mitochondrial respiration. 